\title{
Shark Tank Challenge
}

Michael Sherman ${ }^{1}$

${ }^{1}$ Affiliation not available

March 8, 2021

\section{Mike Sherman}

Grade- 3rd Grade

Subject- Innovation Lab

Lesson Length: 75 Minutes

Overview: Students will receive bags with a few different items along with a task card and then create a model of a product that will go along with their task card. After making their product, students will create a presentation based off of the show "Shark Tank" using their iPads and the Google Slides program, in the hopes that the billionaire judge (their teacher) will invest in their product. Presentations will be limited to 5 minutes per group.

Task Cards Include: A product that would go in an office, a product to provide shade at the beach, a product to help build a treehouse, a product to make long car trips easier, and a product to travel with on an airplane.

Supply Bag: 5 paper clips, 5 large craft sticks, a one foot strip of masking tape, 1 sheet of tinfoil, 2 sheets of tissue paper, 4 pipe cleaners.

\section{Standards Addressed}

Next Generation Science Standard- 3-5 ETS 1-1

Define a simple design problem reflecting a need or a want that includes specified criteria for success and constraints on materials, time, or cost.

Next Generation Science Standard- 3-5 ETS 1-2

Generate and compare multiple possible solutions to a problem based on how well each is likely to meet the criteria and constraints of the problem.

ISTE Standard- $4 \mathrm{~b}$.

Students select and use digital tools to plan and manage a design process that considers design constraints and calculated risks.

Common Core Math Standard- MP-5

Use appropriate tools strategically.

\section{Multimedia}

https: //www youtube $\cdot$ com/watch?v=k3PY_p_M- 8 w\&t=115s

(First two minutes so that students can see the Scrub Daddy sales pitch) 
Whole Group/Anticipatory Set: I will review classroom rules and expectations. We will discuss as a group what are expected and unexpected uses of material as well as how working as a team should look. We will also talk about creativity and how presenting their items should look. I will explain the task and then have a turn and talk opportunity for the students to begin to generate ideas for their mystery bag products. Then I will discuss the project with the students, review the time frame that they will be using, and then project expectations.

Next, I will play a clip from the television show Shark Tank to give the students an idea of how their team should present their project. After the clip is done and I check for student understanding, I will place the students in their teams, give them their supply bag and task card, and let them begin the design process.

Small Groups: Students will be placed into groups and will begin the design process. This will begin with brainstorming and students sharing their ideas with each other after reading their task card and going through their supply bag. Next, the students will blueprint their ideas with a pencil and a sheet of paper. The blueprinting portion of the design process will be followed up with the students beginning to build their invention. After the students have created their invention, they will test it out and then look for ways to improve it.

Once students are happy with their invention, they will begin the process of presenting their invention by creating a slideshow using the Google Slides program. Students will need to write a script and brainstorm effective ways to present their invention, with the goal in mind of having their invention funded by an investor.

Presentations: Groups will take the stage and present their invention to their billionaire investor and their classmates. Prior to presentations, I will go over proper audience etiquette with the students.

Closing: As a whole group, we will share what worked and what did not work with some of the different creations after presenting them to the class.

Materials: 5 paper clips, 5 large craft sticks, a one foot strip of masking tape, 1 sheet of tinfoil, 2 sheets of tissue paper, 4 pipe cleaners, iPads, pencil, paper.

Outcome: Students will be able to work together to solve problems and create different innovative inventions to solve the problem that they were given with a limited amount of time and material. 